\title{
TWO NEW ALIEN SLUGS, KRYNICKILLUS MELANOCEPHALUS KALENICZENKO, 1851 AND TANDONIA KUSCERI (H. WAGNER, 1931), ARE ALREADY WIDESPREAD IN HUNGARY
}

\author{
Ágnes Turóci ${ }^{1}$, Zoltán Fehér ${ }^{2}$, Virág KrízsiK ${ }^{3}$ and Barna PÁll-Gergely ${ }^{4}$ \\ ${ }^{1}$ Plant Protection Institute, Centre for Agricultural Research \\ H-1022 Budapest, Herman Ottó út 15, Hungary \\ E-mail: turoci.agnes@agrar.mta.hu,https://orcid.org/0000-0001-5925-3860 \\ ${ }^{2}$ Department of Zoology, Hungarian Natural History Museum \\ H-1088 Budapest, Baross u. 13, Hungary \\ E-mail: feher.zoltan@nhmus.hu,https://orcid.org/0000-0002-4888-1156 \\ ${ }^{3}$ Department of Zoology, Hungarian Natural History Museum \\ H-1088 Budapest, Baross u. 13, Hungary \\ E-mail: krizsik.virag@nhmus.hu, https://orcid.org/0000-0002-4050-8357 \\ ${ }^{4}$ Plant Protection Institute, Centre for Agricultural Research \\ H-1022 Budapest, Herman Ottó út 15, Hungary \\ E-mail: pall-gergely.barna@agrar.mta.hu,https://orcid.org/0000-0002-6167-7221
}

Two slug species (Krynickillus melanocephalus Kaleniczenko, 1851 and Tandonia kusceri (H. Wagner, 1931)) are reported from Hungary for the first time. Identification was supported by anatomical examination in both, and molecular data in the latter species. A citizen science survey applying a Realtime Social Networking Service (RSNS) method using Facebook posts revealed that both species are already widespread in Hungary, i.e. Krynickillus melanocephalus is reported from 14 and Tandonia kusceri from 26 sites. So far, we received no reports on any damage caused by these two slug species. Nevertheless, we treat them as potential horticultural pests requiring further attention.

Key words: alien slug, citizen science, Realtime Social Networking Service method, distribution, Mollusca, Krynickillus melanocephalus, Tandonia kusceri

\section{INTRODUCTION}

Spreading of invasive species means one of the most serious threats to biodiversity, and poses a great challenge to the economy as we try to mitigate the damages they cause (Pejchar \& Mooney 2009, Vilì et al. 2011, Early et al. 2015). Publications on biological invasions have increased dynamically in the last 20 years (Simberloff 2004). Beyond natural range expansion, which might be an inherent feature of several species, transportation of goods and tourism contributes enormously to the fast spreading of invasive species (BERGEY et al. 2014). An immanent nature of biological invasions is that invasive species typically spread much faster than researchers could track using traditional data collecting and monitoring methods. Thus, alternative approaches are needed to follow up the speed, direction and nature of such dispersals. This point is where citizen science comes in. 
Citizen science allows non-professionals to participate in scientific research, mainly in data collection and data processing (Bonney et al. 2009; McKINLEY et al. 2017). This task has an increasing importance in environmental and biodiversity research nowadays. The main advantage of collecting data by means of citizen science is that a great amount of reliable data can be collected within a short period of time. This means that implementing a citizen science project usually needs less effort and infrastructural investment compared to conventional ways of data collection (Kosmala et al. 2016).

Several terrestrial slug species have huge spreading potential and able to establish populations outside of their native range (WIKTOR 2000, KozlowsKI 2012, Rowson et al. 2014, ZAJĄC et al. 2017). Some of them are considered serious crop and horticultural pests (Douglas \& ToOKer 2012). Therefore, monitoring the spreading of slug populations is economically important. Last year (2019), we (Ágnes Turóci and Barna Páll-Gergely) intensively collected slugs all over Hungary as part of a country-wide faunal survey. Our sampling efforts resulted in the discovery of two potentially invasive slug species (Krynickillus melanocephalus Kaleniczenko, 1851 and Tandonia kusceri (H. Wagner, 1931)) not reported from the country before. Both are relatively largesized with some clearly recognizable external characters, making them ideal targets for a citizen science-based survey. To reveal the current distribution of these two newcomers, we applied a Realtime Social Network Service method, as described in PÁll-Gergely et al. (2019). Namely, we asked the followers of the private Facebook profile of PÁlL-Gergely (one post per each species) to report on occurrences all over the country.

Here we report two slug species, K. melanocephalus and T. kusceri from Hungary for the first time, and based on our data received from citizen scientists we show that both species are already widespread in Hungary.

\section{MATERIALS AND METHODS}

\section{Data collection}

After the first finding and identification of the two new alien species, the senior author (Barna Páll-Gergely) posted calls on his private Facebook page (one for each species) accompanied by photographs of living animals and description of both species' key traits, in order to collect field observation records from citizen scientists. The first call about Tandonia kusceri was posted on 27 May 2019, whereas that about Krynickillus melanocephalus was posted on 15 October 2019. Occurrence records were only accepted when accompanied by collected specimens and/or photographs.

In parallel, we followed the uploaded animal photos of a citizen science webpage named Fajbook (https://www.fajbook.hu/). Fajbook is a Hungarian developed webpage to acquaint amateur nature photographers with Hungarian species. Users uploaded 186 slug photos since it has started (December 2018). 


\section{Identification}

Both slug species were identified based on the morphology, colouration of the body, and genital traits based on WiктоR $(1987,2000)$. Due to the presence of two congeners in Hungary (Tandonia budapestensis (Hazay, 1880) and Tandonia rustica (Millet, 1843)), the morphology-based identification of T. kusceri was confirmed also by barcoding, using partial sequences of the mitochondrial cytochrome oxydase subunit I (COI) and the $16 \mathrm{~S}$ rRNA genes.

\section{Handling and imaging of specimens}

We took photos of the living individuals in three standard directions: dorsal, right side (both extended and contracted shape) and ventral (sole). After photographing, we killed them in $20 \%$ ethanol to prevent extreme contraction and preserved the specimens in $75 \%$ ethanol.

Photos were taken by the following equipment: Canon EOS 2000d camera with Tamron SP AF90mm F/2.8 Di MACRO 1:1 macro objective. 2 studio flashbulbs (BlitzBirne Mikrosat) were activated by an external flash on the camera. A white umbrella was used to collect bounced light.

Dissection was implemented with Zeiss Stemi 305 stereomicroscope. After the preparation of the copulatory organs, we took pictures of them with Keyence VHX5000 digital microscope.

\section{DNA analysis}

Sequences are deposited in the GenBank under accession numbers EU413569EU41366.

Studied material: Seven T. kusceri specimens were used for DNA sequence analysis. For DNA isolation we used $96 \%$ ethanol-preserved specimens. Ethanol-preserved voucher specimens are deposited in the Hungarian Natural History Museum, Budapest (HNHM).

DNA samples: DNA samples were extracted from foot tissues using the DNeasy Blood and Tissue Kit (QIAGEN, Hilden, Germany) according to the manufactures's instructions. The obtained genomic DNA samples are deposited in the Collection of Genetic Resources at the Molecular Taxonomy Laboratory of the Hungarian Natural History Museum. For all the samples, we attempted to amplify sections of the mitochondrial cytochrome c oxidase subunit 1 (COI) using the standard LCO 1490 / HCO 2198 primer pair (Folmer et al. 1994) and the mitochondrial 16S rRNA gene using the 16Sbr-H / 16Sar-L primer pair (Palumbi et al. 1991).

Polymerase chain reactions (PCR) for the 16SrRNA were performed in $25 \mu \mathrm{L}$ volumes with $0.2 \mathrm{mM}$ each dNTP, $0.2 \mu \mathrm{M}$ each primer, $2.5 \mu \mathrm{L}$ of 10X DTaqPCR puffer, 0.5 $\mathrm{mM} \mathrm{MgCl}{ }_{2}$ and $0.15 \mu \mathrm{L}$ of $5 \mathrm{U}$ Dream Taq Polymerase (Thermo Fisher Scientific, Waltham, MA, USA). PCRs started with 3 min at $95^{\circ} \mathrm{C}$, followed by 30 cycles with $30 \mathrm{sec}$ at $95^{\circ} \mathrm{C}, 90$ sec at $47^{\circ} \mathrm{C}$ annealing temperature, $90 \mathrm{sec}$ at $72{ }^{\circ} \mathrm{C}$ and a final extension for $3 \mathrm{~min}$ at $72{ }^{\circ} \mathrm{C}$.

For the COI, PCR reactions were performed in $25 \mu \mathrm{L}$ volumes with $0.2 \mathrm{mM}$ each $\mathrm{dNTP}, 0.4 \mu \mathrm{M}$ each primer, $2.5 \mu \mathrm{L}$ of 10X DTaqPCR puffer, $1.25 \mu \mathrm{L} 5 \mathrm{~V} \%$ DMSO and 0.15 $\mu \mathrm{L}$ of $5 \mathrm{U}$ Dream Taq Polymerase (Thermo Fisher Scientific, Waltham, MA, USA). PCRs for COI started with $3 \mathrm{~min}$ at $95^{\circ} \mathrm{C}$, followed by 30 cycles with $1 \mathrm{~min}$ at $95^{\circ} \mathrm{C}, 1 \mathrm{~min}$ at $44^{\circ} \mathrm{C}$ annealing temperature, $1 \mathrm{~min}$ at $72{ }^{\circ} \mathrm{C}$ and a final extension for $3 \mathrm{~min}$ at $72{ }^{\circ} \mathrm{C}$. 
Purification and bidirectional sequencing were performed at the Molecular Taxonomic Laboratory of the HNHM using the PCR primers.

Barcoding: Alignments were done by the online version of MAFFT (https://mafft. cbrc.jp/alignment/server/) employing the default method (КАтон \& STANDLEy 2013). This resulted in a $430 \mathrm{bp} 16 \mathrm{~S}$ and a $655 \mathrm{bp}$ COI alignment. Two COI haplotypes differed in 2 point mutations and two $16 \mathrm{~S}$ haplotypes that differed in an indel and a point mutation.

Similar sequences were searched in the GenBank using the megablast program of The Basic Local Alignment Search Tool (BLAST) (https://blast.ncbi.nlm.nih.gov/Blast.cgi) with default settings (Palumbi 1991, Folmer 1994).

\section{RESULTS}

\section{Locality data of Krynickillus melanocephalus (Fig. 1)}

HU, Borsod-Abaúj-Zemplén county, Bodrogkeresztúr, Ady utca 5, 110 m a.s.l., 48.1588 N, $21.3550^{\circ} \mathrm{E}$, “Inlot. Fruitery, grassy, diverse vegetation." Obs. Z. Petrovics, 16 October 2019 (photo only)

HU, Borsod-Abaúj-Zemplén county, Bodrogkeresztúr, Óvásártér utca, $110 \mathrm{~m}$ a.s.l., $48.1602^{\circ} \mathrm{N}, 21.3581^{\circ} \mathrm{E}$, Obs. Z. Petrovics, 16 October 2019 (photo only)

HU, Borsod-Abaúj-Zemplén county, Bodrogkeresztúr, Dózsa utca, $110 \mathrm{~m}$ a.s.l., $48.1573^{\circ} \mathrm{N}$, $21.3571^{\circ} \mathrm{E}$, Obs. K. Varga, 6 October 2019 (photo only)

HU, Győr-Moson-Sopron county, Gyarmat, in the crossroads of Fő and Magyar streets, 140 $\mathrm{m}$ a.s.1., $47.4610^{\circ} \mathrm{N}, 17.4869^{\circ} \mathrm{E}$, Obs. T. Szakács, 31 October 2019 (photo only)

HU, Komárom-Esztergom county, Tata, “Öreg-tó” (lake), $135 \mathrm{~m}$ a.s.l., $47.6469^{\circ} \mathrm{N}, 18.3278^{\circ} \mathrm{E}$, Leg. É. Balaskó Péterné, 3 October 2019, HNHM 104523 (3 specimens)

HU, Komárom-Esztergom county, Tata, “Öreg-tó” (lake), $140 \mathrm{~m}$ a.s.1., $47.6296^{\circ} \mathrm{N}, 18.3312^{\circ} \mathrm{E}$, Leg. É. Balaskó Péterné, 20 October 2019, HNHM 104524 (3 specimens)

HU, Komárom-Esztergom county, Tatabánya, Nyárfa utca, $150 \mathrm{~m}$ a.s.l., $47.5728^{\circ} \mathrm{N}$, $18.4126^{\circ} \mathrm{E}$, " 1 specimen in my garden, green belt (around the city), rich vegetation." Obs. J. Tószegi, 4 November 2019 (photo only)

HU, Pest county, Alsógöd, $135 \mathrm{~m}$ a.s.l., $47.6727^{\circ} \mathrm{N}, 19.1534^{\circ} \mathrm{E}$, “The mane of the way out of the city is "Topolyás dülo". Turn to the right there is a power current wire, they were on the dirt road under the wire." Leg. O. Zelenák, 20 October 2019, HNHM 104525 (3 specimens)

HU, Pest county, Budakeszi, land reg. ref.: 0210/12., "Budakeszi Vadaspark" (Budakeszi Wildlife Park), $305 \mathrm{~m}$ a.s.l., $47.5256^{\circ} \mathrm{N}, 18.9261^{\circ} \mathrm{E}$, "I have found ca. 50 specimens in the Budakeszi Wildlife Park. I have collected some of them alive. 3 o' clock pm, light drizzle. In front of the bear yard. West slope, among the thick leaf litter of pedunculate oak." Leg. Zs. Szilágyi, 5 November 2019, HNHM 104527 (13 specimens)

HU, Pest county, Fót, "Fótfürdo"” station from the Árvácska utca, $165 \mathrm{~m}$ a.s.l., $47.6224^{\circ} \mathrm{N}$, $19.2006^{\circ} \mathrm{E}$, Obs. E. Tamás, 30 October 2019 (photo only)

HU, Pest county, Isaszeg, Dózsa Gy. utca 28, $185 \mathrm{~m}$ a.s.l., $47.5345^{\circ} \mathrm{N}, 19.4020^{\circ} \mathrm{E}$, Leg. K. Timár-Geng, 30 October 2019, HNHM 104526 (1 specimen)

HU, Somogy county, Siófok, Diófás utca 109, $150 \mathrm{~m}$ a.s.l., $46.8574^{\circ} \mathrm{N}, 18.0204^{\circ} \mathrm{E}, \mathrm{Obs}$. A. Kálmán, 8 November 2019 (photo only) 
HU, Somogy county, Zamárdi, blind path in the crossroads of Széchényi and Csokonai streets, $105 \mathrm{~m}$ a.s.l., $46.8823^{\circ} \mathrm{N}, 17.9290^{\circ} \mathrm{E}$, "I have found them in the leaf litter of the bio apple tree." Obs. Á. Sára, 17 October 2019 (photo only)

HU, Veszprém county, Pápa, in the crossroads of Kisfaludy and Tompa Mihály streets, $140 \mathrm{~m}$ a.s.l., $47.3388^{\circ} \mathrm{N}, 17.4567^{\circ} \mathrm{E}$, "Almost entirely at the railway cossing." Obs. T. Szakács, 11 November 2019 (photo only)

\section{Locality data of Tandonia kusceri (Fig. 1)}

HU, Budapest, II. district, Herman Ottó út 15, Plant Protection Institute, $175 \mathrm{~m}$ a.s.l., $47.5146^{\circ} \mathrm{N}, 19.0113^{\circ} \mathrm{E}$, Leg. B. Páll-Gergely \& Á. Turóci, 8 July 2019, HNHM 104512 (3 specimens)

HU, Budapest, II. district, "Kass János lépcső" (stairs) between Vadorzó and Herman Ottó utca, $150 \mathrm{~m}$ a.s.l., $47.5119^{\circ} \mathrm{N}, 19.0121^{\circ} \mathrm{E}$, Leg. B. Páll-Gergely, 10 May 2019, HNHM 104505 (1 specimen). GenBank accession number: Taku-03_16S: MT241832, Taku04_16S: MT241833, Taku-05_16S: MT241834, Taku-03_COI: MT246857, Taku-04_COI: MT246858, Taku-05_COI: MT246859.

HU, Budapest, II. district, "Kass János lépcső" (stairs) between Vadorzó and Herman Ottó utca, 150 m a.s.l., 47.5119² N, 19.0121E, Leg. B. Páll-Gergely, 9 April 2019, HNHM 104516 (7 specimens)

HU, Budapest, II. district, "Kass János lépcső" (stairs) between Vadorzó and Herman Ottó

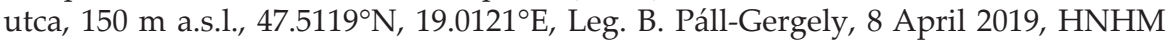
104517 ( 1 specimen)

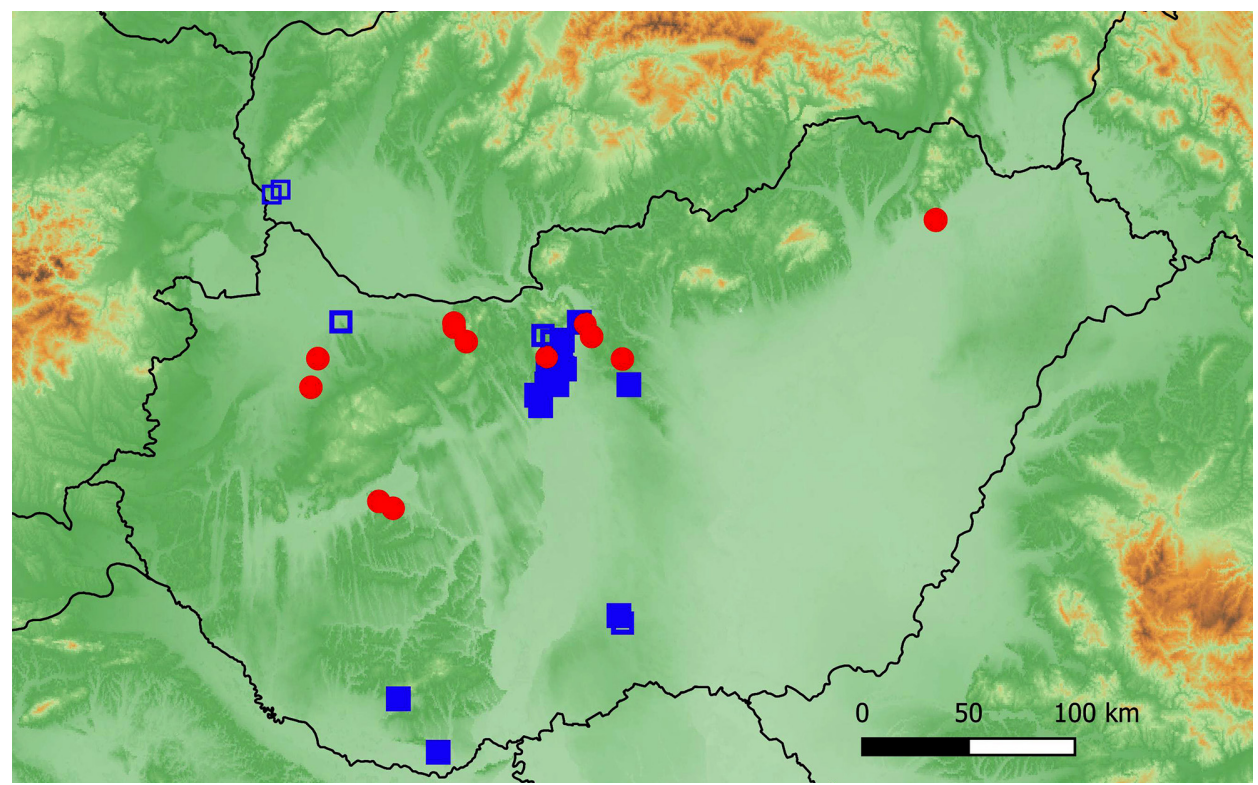

Fig. 1. Distribution of Krynickillus melanocephalus Kaleniczenko, 1851 (circle) and Tandonia kusceri (H. Wagner, 1931) (filled square: locality with specimens, empty square: locality with photos). Slovakian localities are from KoráBEк et al. (2016) 
HU, Budapest, XI. district, Radvány utca 10, $140 \mathrm{~m}$ a.s.l., 10, $47.4841^{\circ} \mathrm{N}, 19.0238^{\circ} \mathrm{E}$, “They have rest mainly under trunks and stones." Leg. M. Szabó, 8 June 2019, HNHM 104509 (14 specimens)

HU, Budapest, XXII. district, XIII. utca, $160 \mathrm{~m}$ a.s.1., $47.4140^{\circ} \mathrm{N}, 18.9966^{\circ} \mathrm{E}$, Leg. É. Süle, 25 May 2019, HNHM 104518 (1 specimen). GenBank accession number: Taku-07_16S: MT241836.

HU Budapest, XII. district, Németvölgyi út 99, “Farkasréti temeto"” (cemetary), $280 \mathrm{~m}$ a.s.l.,

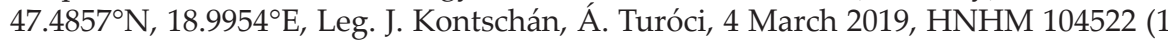
specimen)

HU Budapest, XII. district, Németvölgyi út 99, "Farkasréti temető" (cemetary), $220 \mathrm{~m}$ a.s.l., $47.4867^{\circ} \mathrm{N}, 19.0050^{\circ} \mathrm{E}$, Leg. Á. Turóci, 30 April 2019, HNHM 104506 (1 specimen). GenBank accession number: Taku-01_16S: MT241831, Taku-02_16S: MT241832. Taku01_COI: MT246855, Taku-02_COI: MT246856.

HU, Budapest, XI. district, Budai Mts, Sas-hegy, on the crossroads of Korompai és Tájék streets, $235 \mathrm{~m}$ a.s.1., $47.4829^{\circ} \mathrm{N}, 19.0152^{\circ} \mathrm{E}$, Leg. Á. Turóci, 5 November 2019, HNHM 104503 (6 specimens)

HU, Budapest, XI. district, Budai Mts, Sas-hegy, $50 \mathrm{~m}$ E of the crossroads of Korompai and Tájék u., along Tájék u., 235 m a.s.l., 47.4829N N, 19.0152E, Leg. Á. Turóci, 5 November 2019, HNHM 104504 (1 specimen)

HU, Budapest, XI. district, Ménesi út, $120 \mathrm{~m}$ a.s.l., $47.4811^{\circ} \mathrm{N}, 19.0397^{\circ} \mathrm{E}$, Obs. Seben Máté, 27 May 2019, HNHM 104520 (1 specimen)

HU, Pest county, Budaörs - Alsószállás, Ribizke utca, land reg. ref.: 8839/4., garden, 215 m a.s.l., $47.4689^{\circ} \mathrm{N}, 18.9376^{\circ} \mathrm{E}$, Leg. Z. Harászi, 7 April 2019, HNHM 104519 (1 specimen). GenBank accession number: Taku-06_16S: MT241835, Taku-06_COI: MT246860.

HU, Pest county, Diósd, Dália utca 13, $195 \mathrm{~m}$ a.s.l., $47.4150^{\circ} \mathrm{N}, 18.9334^{\circ} \mathrm{E}$, “Under a heap of brushwood." Leg. L. Mezőfi, 8 June 2019, HNHM 104510 (4 specimens)

$\mathrm{HU}$, Pest county, Mende, near the bank along the main road, $160 \mathrm{~m}$ a.s.l., $47.4285^{\circ} \mathrm{N}$, $19.4485^{\circ}$ E, Leg. M. Halász, 28 May 2019, (citizen scientist via Facebook) HNHM 104507 (3 specimens)

HU, Pest county, Pilisvörösvár, Piliscsabai út 51, $220 \mathrm{~m}$ a.s.l., $47.6166^{\circ} \mathrm{N}, 18.8929^{\circ} \mathrm{E}$, “Garden (old paddling pool-under the foil, which I used for suppressing the weed)." Leg. B. Kiss, 28 October 2019 (photo only)

HU, Pest county, Solymár, railway station, $145 \mathrm{~m}$ a.s.1., $47.5960^{\circ} \mathrm{N}, 18.9501^{\circ} \mathrm{E}$, Obs. E. Hornung, 6 November 2019 (photo only)

HU, Pest county, Százhalombatta, Iskola utca, $120 \mathrm{~m}$ a.s.l., $47.3224^{\circ} \mathrm{N}, 18.9020^{\circ} \mathrm{E}$, Obs. Á. Turóci, 13 November 2019 (personal observation)

HU, Pest county, Szentendrei island, Szigetmonostor, $110 \mathrm{~m}$ a.s.l., $47.6793^{\circ} \mathrm{N}, 19.1184^{\circ} \mathrm{E}$, Leg. D. Csanádi, 19 August 2019, HNHM 104513 (1 specimen)

HU, Pest county, Tárnok, railway station, $105 \mathrm{~m}$ a.s.l., $47.3655^{\circ} \mathrm{N}, 18.8734^{\circ} \mathrm{E}$, Leg. TóthTuróci family, 8 September 2019, HNHM 104514 (1 specimen)

HU, Pest county, Törökbálint, 195 m a.s.l., $47.4219^{\circ}$ N, $18.9426^{\circ} \mathrm{E}$, Obs. L. Mezőfi, 25 June 2019 (photo only)

HU, Pest county, Üröm, Jókai utca, $220 \mathrm{~m}$ a.s.l., $47.6009^{\circ} \mathrm{N}, 19.0169^{\circ} \mathrm{E}$, old wine cellar, Leg. V. Németh, 15 November 2019, HNHM 104521 (1 specimen)

HU, Bács-Kiskun county, Kiskunhalas-Fejetéki Moor Nature Reservation. "Farm" along a road from road no. 53 towards Kiskunhalas-Fejetéki Moor Nature Reservation, 125 m

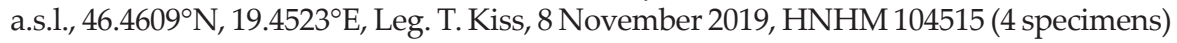


HU, Bács-Kiskun county, Kiskunhalas, bus station, $125 \mathrm{~m}$ a.s.l., $46.4300^{\circ} \mathrm{N}, 19.4768^{\circ} \mathrm{E}, \mathrm{Obs}$. T. Kiss, 13 November 2019 (photo only)

HU, Baranya county, Cserkút, periphery, Szikuti dűlő, "Malom" garden centre, $135 \mathrm{~m}$ a.s.l., $46.0620^{\circ} \mathrm{N}, 18.1281^{\circ} \mathrm{E}$, “I can't remember when I saw this species at the first time, but it is not so rare around here... 4-5 slugs pop up under every left bucket." Leg. P. Mislyenácz, 6 June 2019, HNHM 104508) (5 specimens)

HU, Baranya county, Nagyharsány, Hegy utca, Under bricks along a wall in the shadow of a fig tree, $105 \mathrm{~m}$ a.s.1., $45.8485^{\circ} \mathrm{N}, 18.3906^{\circ} \mathrm{E}$, Leg. E. Kiss, J. Kontschán, D. Murányi, Á. Turóci, 5 July 2019, HNHM 104511 (3 specimens)

HU, Győr-Moson-Sopron county, Győr, Győr-Ménfőcsanak, between Győzelem and Csanakhegyi streets, $145 \mathrm{~m}$ a.s.l., $47.6208^{\circ} \mathrm{N}, 17.6157^{\circ} \mathrm{E}$, “Our plot reach up to the middle of the hill and these slugs were at the end of the yard, so we found them approximately in the middle of the area delimited by: Győzelem utca 97-99 and Csanakhegyi utca 28-30." Obs. M. Kuroli, Z. Kuroli, 11 November 2019 (photo only).

\section{Results of data collection by citizen science method}

The Facebook post of K. melanocephalus was shared ca. 560 times within a week, whereas that of T. kusceri was shared ca. 50 times. These posts have been shared very few (ca. 10 and ca. 5, respectively) times after the first week.

Krynickillus melanocephalus was detected altogether at 14 sites (12 of them from the Facebook), from 11 different towns; 1 town with 2 different detection spots (Tata) and 1 town with 3 different detection spots (Bodrogkeresztúr). We received photos from only 8 localities, living specimens from 5 localities, both from the western and northern parts of the country. We received 23 specimens altogether.

Data referring to habitat characteristics vary on a large scale, but the common feature is human disturbance. Nearly all our data came from inhabited areas, although mainly from rural sites or less disturbed semi-natural regions: factory yards (Alsógöd) and a Wildlife Park (Budakeszi).

Tandonia kusceri was detected altogether at 26 sites (11 by the authors, 14 from Facebook, 1 from Fajbook). Twenty cities, towns or districts of Budapest were represented. Three spots of the 26 sites were in II. distr., 2 of them in XII. distr., 3 of them in XI. distr. of Budapest and 2 Kiskunhalas. In 21 cases, we received living specimens and in 5 cases, we got only photos. We received and collected 60 specimens altogether.

Anthropogenic effects seemingly play a greater role in the distribution of T. kusceri than that of K. melanocephalus. Our data show that the main detection spots of T. kusceri are within cities. Cemetery in the middle of the capital of Hungary and other city centres were common observational localities.

We have no information about the potential economic damage caused by K. melanocephalus and T. kusceri in Hungary yet. 


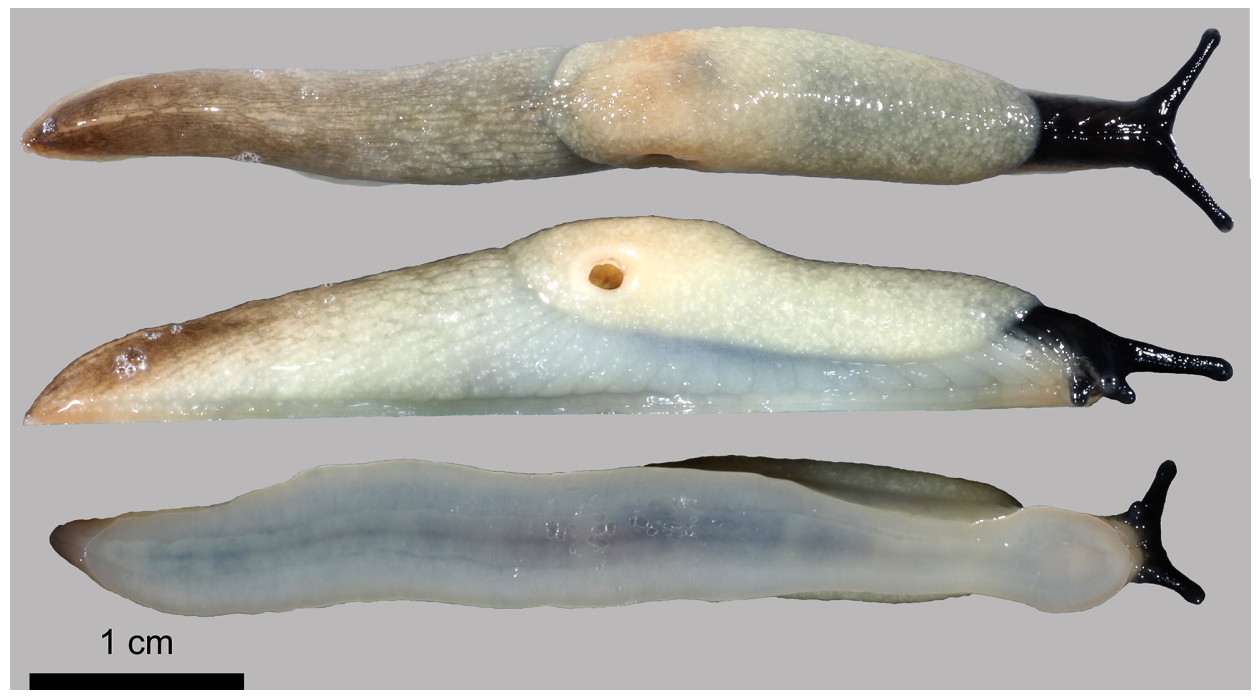

Fig. 2. Living individual of Krynickillus melanocephalus Kaleniczenko, 1851 (HNHM 104523)

New results on morphology

Examination of the body of living $K$. melanocephalus specimens resulted in the discovery of several features hitherto unknown in the literature. These are the following:

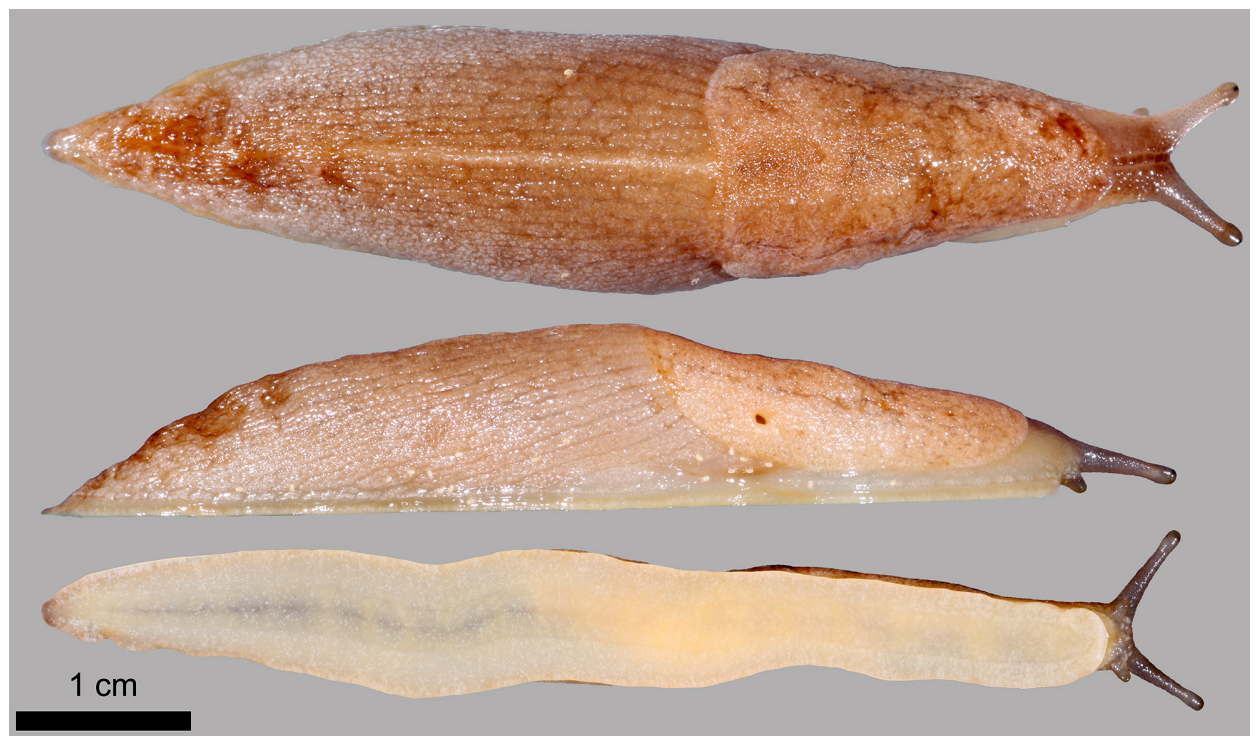

Fig. 3. Living individual of Tandonia kusceri (H. Wagner, 1931) (HNHM 104516) 
The body size of the living specimens was larger than the ones given by WiктоR (2000). We examined the populations from Alsógöd, Budakeszi, Isaszeg and Tata, where body length generally reached $60 \mathrm{~mm}$ (one specimen from Budakeszi, one from Isaszeg and two specimens from Tata). Moreover, a specimen from Alsógöd reached $75 \mathrm{~mm}$. The tail is usually brownish, which was also not mentioned in the literature (WIKTOR 2000). The posterior part of the mantle is often lighter than the anterior part. This is caused by the most characteristic feature of the species: the head, tentacles and nape are deep black and show through the forepart of the mantle. Beyond its clearly distinguishable black colouration, the nape has got a typical fishbone-like groove pattern (Fig. 2).

Tandonia kusceri showed an extremely diverse external morphology. Almost completely light pink colouration without any spots (Fig. 3), and quite dark variants were also represented in our collection. Juveniles were captured on one occasion: they have exactly the same appearance than adults (well visible keel reaches to the mantle edge, colouration, etc).

\section{Results of DNA barcoding}

We found that $16 \mathrm{~S}$ sequences of Taku-1, Taku- 6 and Taku-7 bear the same haplotype as T. kusceri isolate kusceriUS1 (KU234274), whereas Taku-3, Taku-4 and Taku-5 16S sequences are the same haplotype as T. kusceri isolate kusceriSK1 (KU234273).

COI sequences of Taku-3, Taku-4 and Taku- 5 are the same haplotype as that of T. kusceri isolate kusceriSK1 (KU641257), whereas Taku-1, Taku-2 and Taku- 6 differs from it by 2 base pairs.

\section{DISCUSSION}

General data on the two new slug species

Krynickillus melanocephalus Kaleniczenko, 1851 originates from Anatolia, the Caucasus and Crimea region (NE Turkey, N Iran) (Wiktor 2000, WelterSchultes 2012) but has been introduced to some other parts of Russian Federation (Likharev 1980, Sysoev \& Schileyko 2009), Ukraine (Korol \& Kornjusin 2002, Sverlova \& Son 2006), Latvia (Dreijers et al. 2017), Lithuania (Stalažs et al. 2017), Belarus (Ostrovsky 2017) and Germany (Bössneck \& Feldmann 2003).

Krynickillus melanocephalus is an easily recognizable slug due to its body colouration. Body length is up to $45 \mathrm{~mm}$ (WIKTOR 2000), but according to our new information, body length generally reaches $60 \mathrm{~mm}$. Colouration dirty whitish, sometimes bluish-grey or leaden grey (WIктоR 2000). Mantle does not exceed $1 / 3$ of the body length. Head and nape always deep black. Sole 
light coloured and often semitransparent to show inner organs. Mucus transparent, water-like.

Tandonia kusceri $(\mathrm{H}$. Wagner, 1931) is native to Balkan region from Bulgaria to the eastern part of the Black Sea (Wiktor 1996, Dedov \& Mitev 2011, WeLTER-Schultes 2012). In the last decade it has been introduced to Crimea (Leonov 2007), Russia (Sysoev \& Schileyko 2009), Moldova (Balashov et al. 2013), Slovakia (KorÁbek et al. 2016), Greece: Samothraki Island (Georgiev 2017) and reported from Montenegro (ТеLebaK et al. 2013). Although it is known for a long time in Ukraine (Odessa, 1902 in Lindholm, 1908 as Amalia rossica; Son 2004, 2009, 2010), the first detection of the species within the Carpathian Basin was only in 2019 (Gural-Sverlova et al. 2019). The first North American record (Brookfield, Illinois, USA) was documented in 2014 by GERBER (2014).

Living specimens of T. kusceri stretch to $100 \mathrm{~mm}$ when crawling (WіктоR 1987). The mantle is $1 / 4$ of the body length (WIKTOR 1987). Colour light pink or pink-brown with diffuse dark spots all over the body. Keel clearly recognizable, and runs along the whole body from the tail to the mantle edge. Dark pigment accumulates mainly in the skin grooves showing reticulate pattern. Sole always light coloured without pigmentation. Mucus whitish, becoming denser when disturbed (WIKTоR 1987).

\section{Notes on identification}

Krynickillus melanocephalus was confused with Krynickillus urbanskii (WiктоR 1971) before WiктоR described the latter species in 1971. Therefore, the relating data of K. melanocephalus in Romania published by Grossu (1957) referred to presumably K. urbanskii.

The reproductive anatomy of $K$. melanocephalus described by WiктоR (2000) largely matches with our observations. However, he described the penis as cylindrical, which is not an appropriate expression of the actual structure. More precisely, the penis consists of a thinner basal (distal) and a swollen apical portion (Fig. 4). Spermatheca, along with the spermathecal duct, is roughly equal to the length of the penis (WIKTOR 2000).

Identification of T. kusceri was more complicated than that of K. melanocephalus, because there are two congeneric species reported from Hungary (Tandonia budapestensis and Tandonia rustica), the latter one being very similar to T. kusceri (Kerney et al. 1979, Welter-Schultes 2012, Horsák et al. 2013, Rowson et al. 2014).

Tandonia budapestensis has a more slender, darker body, and possesses an irregular but rounded penis. The externally similar T. rustica (Fig. 5) also possesses some outer traits which distinguish from T. kusceri. Tandonia kusceri is ash-grey-pink with many small blackish spots, which do not contrast with the 


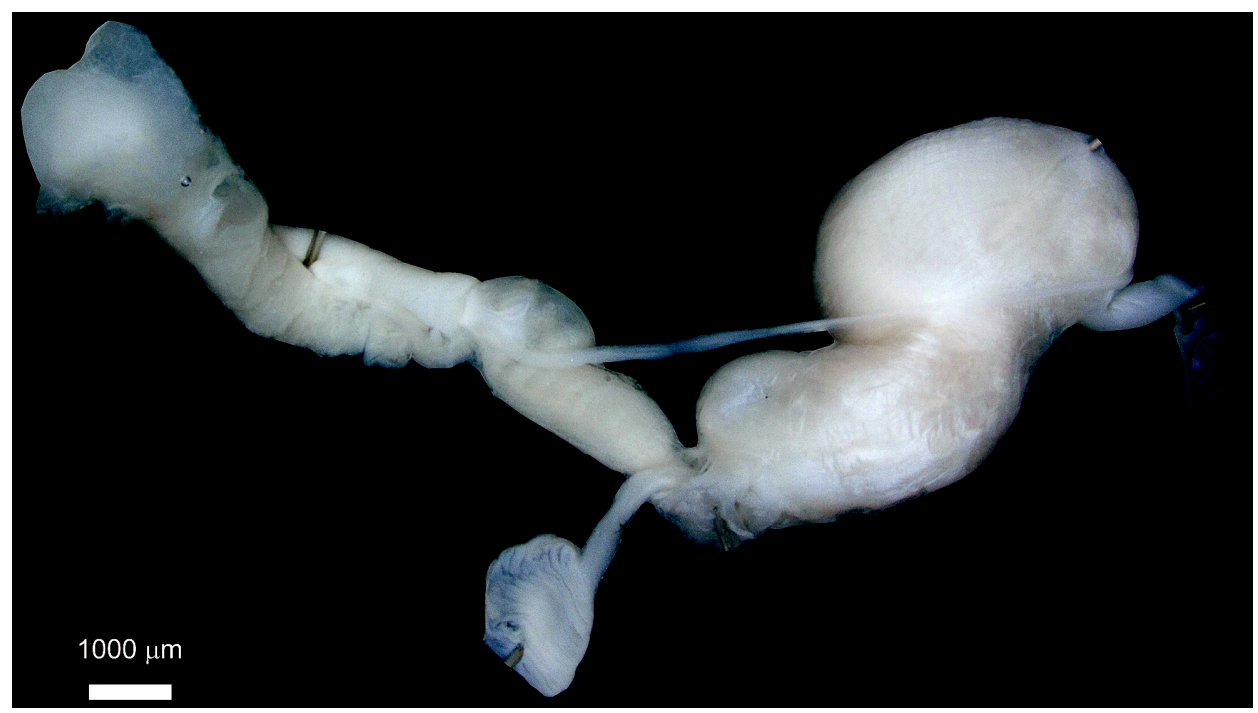

Fig. 4. Reproductive anatomy of Krynickillus melanocephalus Kaleniczenko, 1851 (HNHM 104527)

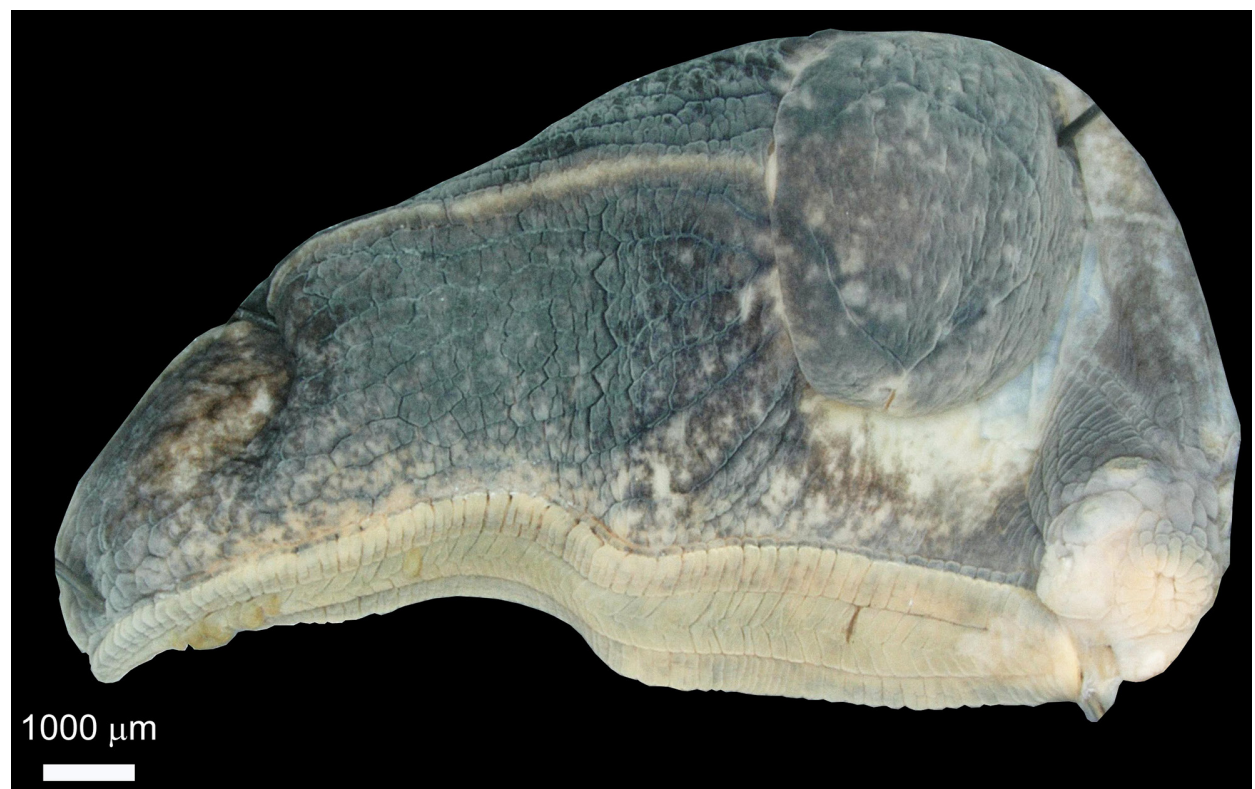

Fig. 5. Conserved specimen of Tandonia rustica (Millet, 1883) (HNHM 104872) 
background. By contrast, T. rustica is much lighter, possessing a yellow-whitish colouration, pattern of sharply delimited black dots, which are smaller and more contrast with the background than that of T. kusceri (WiктоR 1987).

Anatomically, T. kusceri can be clearly distinguished by exceptionally long vas deferens and epiphallus (5-6 times longer than penis), with its special morphology, which is almost always spirally coiled and intensely folded or looped (Fig. 6). This cannot be observed neither in case of T. budapestensis, nor in T. rustica. Spermatheca spherical, its duct is long, tubular (WiкTOR 1987, Gerber 2014, KorábeK et al. 2016). By contrast, T. rustica possesses an elongated spermatheca, which is apically pointed (Fig. 7) and an elongated epiphallus, which is wider than the penis. The proximal boundary of epiphallus and penis hard to distinguish. Epiphallus much shorter than that of $T$. kusceri (WiкTOR 1987).

Korábé et al. (2016) mentioned that T. rustica data from Hungary might refer to misidentified T. kusceri. Two of the three formerly published Hungar-

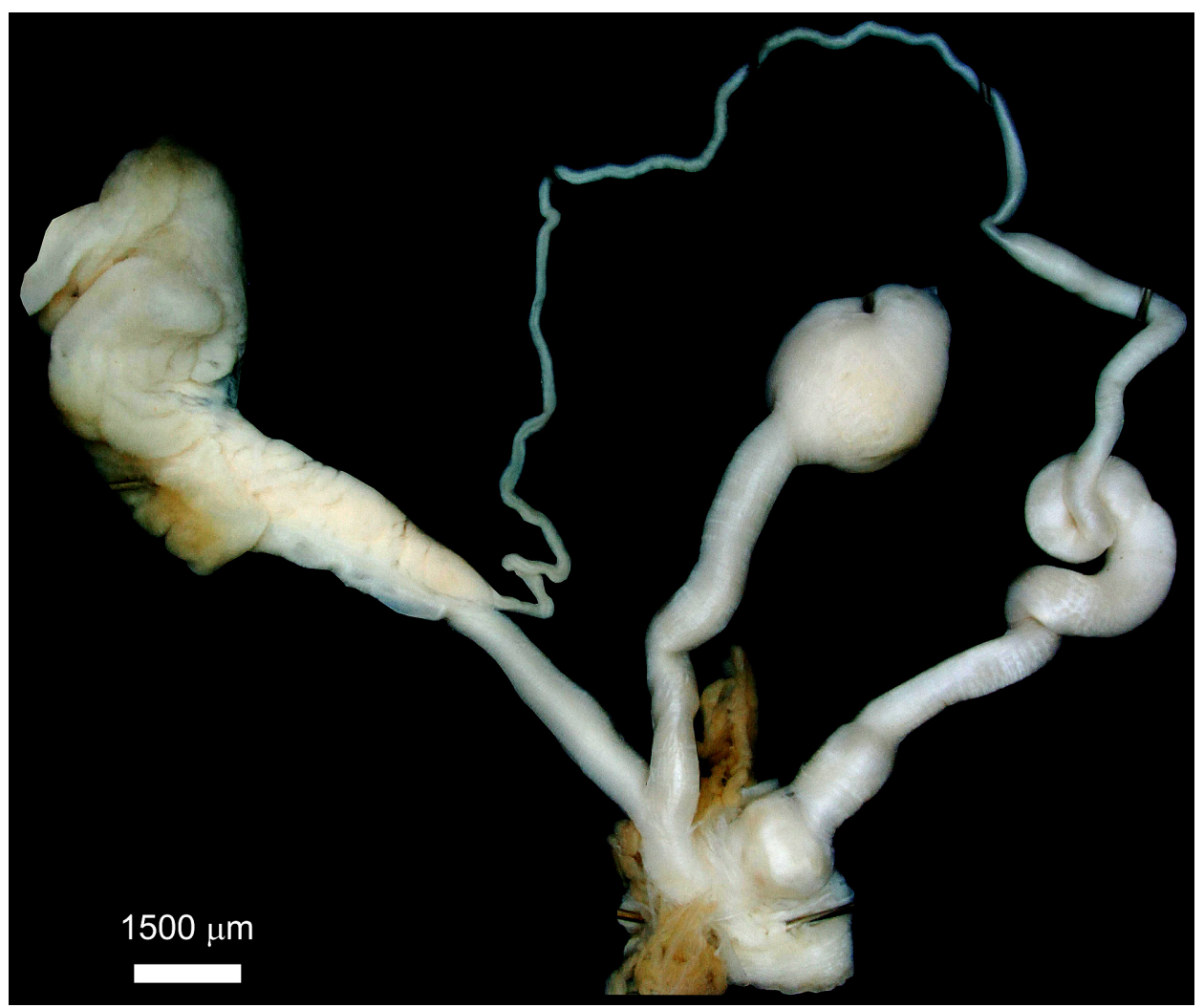

Fig. 6. Reproductive anatomy of Tandonia kusceri (H. Wagner, 1931) 

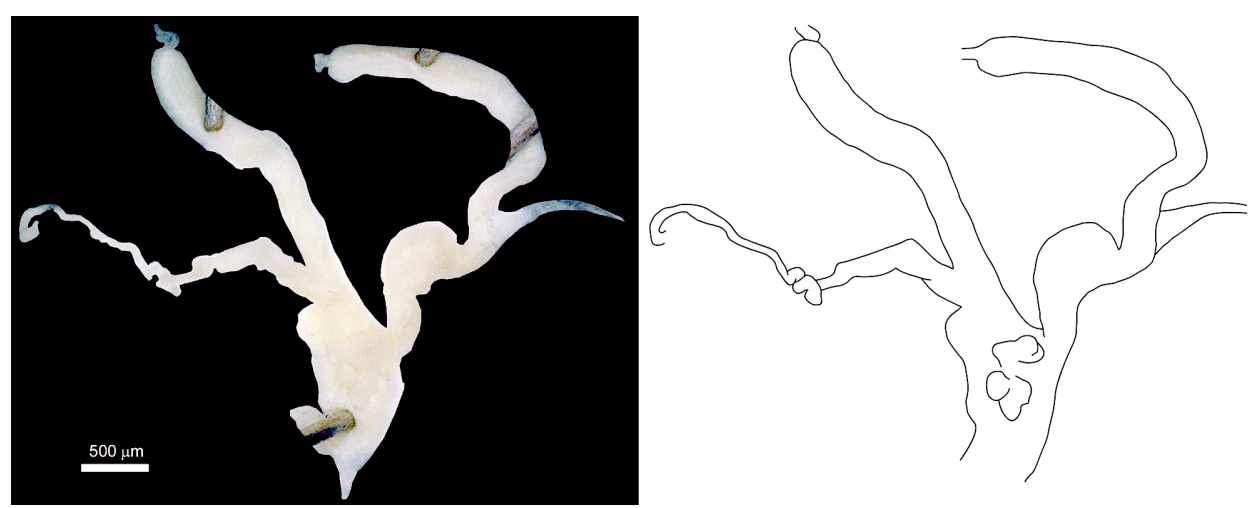

Fig. 7. Reproductive anatomy of Tandonia rustica (Millet, 1883) (HNHM 104872). Drawing: Barna Páll-Gergely

ian data of T. rustica were impossible to check because the accessible information published in Pintér and SuARa (2004) was not sufficient to search for the specific individuals under discussion in the Mollusca Collection of the HNHM (Esztergom: nursing home, and Kőszeg, see Pintér \& SuARa 2004). The third one (Györ, see FehÉr \& Gubányı 2001), which is stored in the Mollusca Collection of the HNHM was investigated and proved to be T. rustica (FeHÉr \& GubánYi 2001). This clarifies that the data of T. rustica were not early records of misidentified T. kusceri, but both species live or at least lived in the country.

\section{Citizen science}

To reveal the current distribution of the two alien slug species, we used the RSNS methods as described in our earlier paper (PÁLL-GERGELY et al. 2019), in which we collected distribution data of invasive helicid land snails Cornu aspersum (O.F. MüLLER, 1774) and Helix lucorum Linnaeus, 1758. Accordingly, after the first Hungarian records were detected of each alien slug species, we posted a Facebook call including photos and remarks on the outer morphology. In the posts, we asked citizen scientists to report occurrences of the alien species accompanied by photos, and asked them to share the posts to reach as many people as possible.

The dynamics of sharing the posts agreed with that of PÁLL-Gergely et al. (2019). Namely, both posts were mostly shared within the first week, and only very few people have shared in afterward. Consequently, we received the most occurrence data within the first week.

The post of K. melanocephalus was shared ca. ten times more than that of T. kusceri, without a clear reason behind this huge difference. We assume that 
the order of the posts might have played a great role. Namely, T. kusceri was posted first, which was probably remembered by the Facebook community. Therefore the second species reached the threshold of recognition more easily, and thus, could be shared by more people. Also, once a post is shared many times, it is likely that it triggers sharing of more and more people, indicating a sharing cascade. Another factor might be the peculiar external morphology of K. melanocephalus, especially the milky body and the clearly recognizable black head.

Despite the fewer shares, we received more locality data in case of $T$. kusceri than that of K. melanocephalus, indicating that the former is probably more common and widespread than the latter. Detection sites were concentrated in the area of the capital city Budapest in case of both species. It remains a question whether it is due to the uneven distribution of the citizen scientists we reached via the Facebook calls or reflects the actual distribution of the species.

It is worth mentioning that the European distribution based on the literature shows a very sporadic prevalence, mainly in the case of K. melanocephalus. Still, the distribution of these species could be more continuous than believed. Our RSNS method was an effective tool to reveal the real-time distributions in Hungary, which is underpinned by the received 14 and 26 sites of K. melanocephalus and T. kusceri, respectively. Thus, we could show how widely it is distributed besides a randomly found population of a potentially invasive animal species. At the same time, it also shows the frequency of the species to each other: from the beginning of 2019 until February 2020, citizen scientists uploaded 186 slug photos to the Fajbook, of which ca. two-third were taken of Arion vulgaris Moquin-Tandon, 1855, and only one was taken of T. kusceri, and none of K. melanocephalus. Citizen scientists mostly live in cities or other urban areas. Therefore citizen science is a very useful approach for surveying species tolerating human disturbance.

\section{Distribution, spreading, economic damages}

Spreading of species could happen by means of human contribution (e.g. horticultural cargos, tourism) but also due to natural range expansion. In most cases, it is difficult to determine which of the two happened (Zemanova et al. 2016). If a species reaches distant areas from its native range in a short period of time and the distribution can be characterised by the diffuse presence at different areas with no connection between them, human contribution probably plays a major role in the range expansion.

In case of K. melanocephalus diffuse presence is obvious in Europe: Latvia: 1997 (ŠTeffek et al. 2008), Germany: 2003 (Bössneck \& Feldmann 2003, in Saxony: 2018 (Borleis 2018)), Ukraine: 2002 (Korol \& Kornjusin 2002). Its 
Hungarian range covers the northern part of the country, which is in agreement with the reported invasions in the countries mentioned above (Ukraine, Germany, Latvia). If spreading continues, we expect this slug to be found in southern Hungary as well.

Horticultural cargos could have a considerable effect on spreading slug species due to their capability to resist disturbance (BERGEY et al. 2014). Slugs can easily survive in the soil of a flower pot in a truck or during a flight. We received data of T. kusceri mainly from Budapest and its vicinity, and from southwestern and northwestern Hungary. The reported occurrences mostly came from cities, indicating that this species is synanthropic, as mentioned by WIKTOR (1987). KorÁBEK et al. (2016) indicated the presence of T. kusceri in the Slovakian capital Bratislava, situated close to the north's Hungarian border. One might believe that as a species originated from the Balkans, T. kusceri might spread from the south to the north continuously or with small jumps. Still, according to the recent data of the distribution, this assumption is not clearly proved and requires further examinations. COI and 16S DNA sequences of Hungarian T. kusceri specimens were found to be closely related to those available in NCBI GenBank (from Slovakia and the USA). Such a pattern of the intraspecific genetic diversity is characteristic for rapidly spreading alien species.

We do emphasize that in some cases, both slug species were found in large quantities, based on personal observations and communication with citizen scientists. Tandonia kusceri specimens infested the streets of Tárnok after dark, on a rainy day (Ágnes Turóci, personal observation). During a 4-5 $\mathrm{km}$ long walk, more than 70 living specimens of this species were observed, without the presence of any other slug species. Similar experience was received by a citizen scientist in the case of K. melanocephalus. More than 50 living specimens were observed in Budakeszi Wildlife Park in a relatively small area under a tree, of which 13 living specimens were sent to us.

Several slug species of the families Milacidae and Agriolimacidae can colonise new territories, and some of them are well documented serious pests (e.g. Tandonia budapestensis, Deroceras reticulatum). In Latvia, K. melanocephalus was documented to consume the fruit of Cucurbita species (Dreijers et al. 2017), which was the first evidence of economic damage caused by K. melanocephalus. In Hungary, we have no such data about damage yet. Nevertheless, K. melanocephalus and T. kusceri spread rapidly across Europe. Therefore, their spreading, and the possible damage they may cause, should be further monitored.

Acknowledgements - We are grateful to all citizen scientists who sent information on slug occurrences. This study was supported by the MTA (Hungarian Academy of Sciences) Premium Post Doctorate Research Program for B. PÁlL-Gergely. 


\section{REFERENCES}

Balashov, I. A., Mikhail, O. S., Viorica, C. \& Welter-Schultes, F. (2013): An updated annotated checklist of the Molluscs of the Republic of Moldova. - Folia Malacologica 21(3): 175-181. http://dx.doi.org/10.12657/folmal.021.021

Bergey, E. A., Figueroa, L. L., Mather, C. M., Martin, R. J., Ray, E. J., Kurien, J. T., Westrop, D. R. \& Suriyawong, P. (2014): Trading in snails: plant nurseries as transport hubs for non-native species. - Biological Invasions 16: 1441-1451. https://doi.org/10.1007/ s10530-013-0581-1

Bonney, R., Cooper, C. B., Dickinson, J., Kelling, S., Phillips, T., Rosenberg, K. V. \& Shirk, J. (2009): Citizen science: a developing tool for expanding science knowledge and scientific literacy. - BioScience 59(11): 977-984. https://doi.org/10.1525/bio.2009.59.11.9

Borleis, F. (2018): Entdeckung von Krynickillus melanocephalus (Kaleniczenko, 1851) in Sachsen. - Mitteilungen der Deutschen Malakozoologischen Gesellschaft 98: 61-68.

Bössneck, U. \& Feldmann, A. (2003): Zur Ausbreitung von Neozoa im Stadtgebiet von Erfurt am Beispiel der Landschnecken Cernuella neglecta (Draparnaud, 1805), Monacha cartusiana (O. Müller, 1774) und Krynickillus melanocephalus Kaleniczenko, 1851 (Mollusca: Gastropoda). - Veröffentlichungen des Naturkundemuseums Erfurt 22: 115-125.

Dedov, I. K. \& Mitev, T. (2011): Mollusks fauna (Mollusca: Gastropoda: Bivalvia) of Mountain Osogovo. - Acta Zoologica Bulgarica 63(1): 37-46.

Douglas, M. R. \& Tooker, J. F. (2012): Slug (Mollusca: Agriolimacidae, Arionidae) ecology and management in no-till field crops with an emphasis on the mid-Atlantic Region. - Journal of Integrated Pest Management 3(1): C1-C9. https://doi.org/10.1603/IPM11023

Dreijers, E., Stalažs, A., Pilāte, D., Jakubāne, I. \& Jundzis, M. (2017): Agricultural importance of Agriolimacidae slugs and the first notes on damage in horticulture made by Krynickillus melanocephalus Kaleniczenko, 1851 (Gastropoda: Agriolimacidae) in Latvia. - Zinātniski praktiskā konference "Lìdzsvarota Lauksaimniecība", 23.02.2017., LLU, Jelgava, Latvija. [in Latvian]

Early, R., Bradley, B. A., Dukes, J. S., Lawler, J. J., Olden, J. D., Blumenthal, D. M., Gonzalez, P., Grosholz, E. D., Ibanez, I., Miller, L. P., Sorte, C. J. B. \& Tatem, A. J. (2015): Global threats from invasive alien species in the twenty-first century and national response capacities. - Nature Communications 7: 12485. https://doi.org/10.1038/ncomms12485

Fenér, Z. \& Gubányi, A. (2001): The distibution of the Hungarian molluscs - The catalogue of the Mollusca Collection of the Hungarian Natural History Museum. - Hungarian Natural History Museum, Budapest, $466 \mathrm{pp}$.

Folmer, O., Black, M., Hoen, W., Lutz, R. \& Vrijenhoek, R. (1994): DNA primers for amplification of mitochondrial cytochrome $C$ oxidase subunit I from diverse metazoan invertebrates. - Molecular Marine Biology and Biotechnology 3: 294-299.

Georgiev, D. (2017): Updated and corrected list of the inland molluscs of Samothraki Island (N Aegean, Greece). - ZooNotes 113: 1-4.

Gerber, J. (2014): First American record of the exotic slug Tandonia kusceri (Gastropoda: Milacidae). - The Nautilus 128(2): 59-63.

Grossu, A. V. \& Lupu, D. (1957): Deroceras (Hydrolimax) melanocephalus, eine kaukasische Limacide in Rumänien. - Archiv für Molluskenkunde 86(4-6): 171-172.

Gural-Sverlova, N., Gleba, V. \& Gural, R. (2019): Einschleppung von Tandonia kusceri (Pulmonata: Milacidae) nach Transkarpatien und Verbreitung von Tandonia-Arten in der Ukraine. - Malacologica Bohemoslovaca 18: 19-26.

Horsák, M., JuřičKová, L. \& PICKA, J. (2013): Měkkýši České a Slovenské republiky. Molluscs of the Czech and Slovak Republics. - Nakladatelství Kabourek, Zlín, 264 pp. 
Katoh, K. \& Standley, D. M. (2013): MAFFT multiple sequence alignment software version 7: Improvements in performance and usability. - Molecular Biology and Evolution 30: 772-780. https://doi.org/10.1093/molbev/mst010

Kerney, M. P., Cameron, R. A. D. \& Jungbluth, J. H. (1983): Die Landschnecken Nord- und Mitteleuropas. - Paul Parey, Hamburg und Berlin, 384 pp.

KorÁbeK, O., ČeJKA, T. \& JuňičKovÁ, L. (2016): Tandonia kusceri (Pulmonata: Milacidae), a slug new for Slovakia. - Malacologica Bohemoslovaca 15: 3-8.

Korol, E. N. \& Kornuusin, A. V. (2002): Introduced population of Krynickillus melanocephalus (Mollusca, Gastropoda, Stylommatophora) recorded in Kyiv and preliminary results of its helminthological investigation. - Vestnik Zoologii 36(6): 57-59.

Kosmala, M., Wiggins, A., Swanson, A. \& Simmons, B. (2016): Assessing data quality in citizen science. - Frontiers in Ecology and the Environment 14(10): 551-560. https://doi. org/10.1002/fee.1436

Kozlowski, J. (2012): The significance of alien and invasive slug species for plant communities in agrocenoses. - Journal of Plant Protection Research 52(1): 67-76. https://doi. org/10.2478/v10045-012-0012-9

Leonov, S.V. (2007): The first record of the Tandonia kusceri (Pulmonata, Milacidae) in Crimea and a few remarks about its natural habitats. - Vestnik Zoologii 41(2): 142.

LikHAREv, I. M. \& WiKTor, A. J. (1980): The fauna of slugs of the USSR and adjacent countries (Gastropoda terrestria nuda). - Fauna SSSR (Novaja serija 122) 3(5): 1-437. [in Russian]

Lindholm, W. A. (1908): Materialien zur Molluskenfauna von Südwestrussland, Polen und der Krim. - Proceedings of the Novorossiysk Natural History Society 31: 199-232.

McKinley, D. C., Miller-Rushing, A. J., Ballard, H. L., Bonney, R., Brown, H., CookPatton, S. C., Evans, D. M., French, R. A., Parrish, J. K., Phillits, T. B., Ryan, S. F., Shanley, L. A., Shirk, J. L., Stepenuck, K. F., Weltzin, J. F., Wiggins, A., Boyle, O. D., Briggs, R. D., Chapin, S. F., Hewitt, D. A., Preuss, P. W. \& Soukup, M. A. (2017): Citizen science can improve conservation science, natural resource management, and environmental protection. - Biological Conservation 208: 15-28. http://dx.doi. org/10.1016/j.biocon.2016.05.015

Ostrovsky, A. M. (2017): New records of synanthropic species of slugs Limacus flavus (Linnaeus 1758) and Krynickillus melanocephalus Kaleniczenko, 1851 (Mollusca, Gastropoda, Stylommatophora) in Belarus. - Ruthenica 27(14): 155-158.

Palumbi, S. R. (1991): The simple fool's guide to PCR. - Department of Zoology and Kewalo Marine Laboratory, University of Hawaii, Honolulu.

PÁll-Gergely, B., Majoros, G., Domokos, T., Juhász, A., Turóci, A., Badacsonyi, L., Fekete, J. \& AsAmi, T. (2019): Realtime Social Networking Service rapidly reveals distributions of non-indigenous land snails in a European capital. - Bioinvasions Records 8(4): 782-792. https://doi.org/10.3391/bir.2019.8.4.06

Pejchar, L. \& Mooney, H. A. (2009): Invasive species, ecosystem services and human well-being. - Trends in Ecology and Evolution 24(9): 497-504. https://doi.org/10.1016/j. tree.2009.03.016

Pintér L. \& SuARa R. (2004): Magyarországi puhatestüek katalógusa hazai malakológusok gyüjtései alapján. (Catalogue of the Hungarian molluscs based on the collectings of Hungarian malacologists). - Hungarian Natural History Museum, Budapest, 574 pp. [in Hungarian]

Rowson, B., Turner, J., Anderson, R. \& Symondson, B. (2014): Slugs of Britain and Ireland. Identification, understanding and control. - FSC Publications/National Museum of Wales, Telford, $136 \mathrm{pp}$. 
Simberloff, D. (2004): A rising tide of species and literature: a review of some recent books on biological invasions. - BioScience 54(3): 247-254. https://doi.org/10.1641/00063568(2004)054[0247:ARTOSA]2.0.CO;2

Son, M. O. (2004): New findings of Tandonia kusceri (Pulmonata, Milacidae) in Ukraine. Vestnik Zoologii 38: 76.

Son, M. O. (2009): Mollusks-invaders in the Ukraine territory: the sources and directions of invasion. - Russian Journal of Biological Invasions No. 2. (in Russian)

Son, M. O. (2010): Alien mollusks within the territory of Ukraine: sources and directions of invasions. - Russian Journal of Biological Invasions 1(1): 137-144. https://doi. org/10.1134/S207511171001008X

Stalažs, A., Dreijers, E., Ivinskis, P., Rimšaité, J. \& Džıugelis, M. (2017): Records of Krynickillus melanocephalus Kaleniczenko, 1851 (Gastropoda: Agriolimacidae) in Lithuania. - Bulletin of the Lithuanian Entomological Society 1(29): 124-128.

Šteffek, J., Stalažs, A. \& Dreijers, E. (2008): Snail fauna of the oldest cemeteries from Riga (Latvia). - Malacologica Bohemoslovaca 7: 79-80.

Sysoev, A. \& SсніLеyко, A. (2009): Land snails and slugs of Russia and adjacent countries. - Pensoft Series Faunistica, No 87. ISSN 1312-0174

Sverlova, N. V. \& Son, M. O. (2006) Mollusks invaders and their place in urban malacocenoses. Pp. 42-59. In: Sverlova, N. V., Khlus, L. N., Kramarenko, S. S., Son, M. O., Leonov, S. V., Vychalkovskaya, N. V., Zemoglyadchuk, K. V., Kyrpan, S. P., Kuzmovich, M. L., Stenko, R. P., Ferencz, O. G., Shrlyaruk, A. N. \& Gural, R. I. (eds): Fauna, ecology and intraspecific variability of terrestrial mollusks in urban environment Lvov. - Gos. Prirodoved. Muzei. [in Ukrainian]

Telebak, B., Brajković, M., Ćurčić, S. (2013): Contribution to the knowledge of the slugs (Gastropoda: Stylommatophora: Limacidae and Milacidae) from Montenegro. - Bulletin of the Natural History Museum 6: 55-64. https://doi.org/10.5937/bnhmb1306055T

Vilà, M., Espinar, J. L., Hejda, M., Hulme, P. E., Jarošík, V., Maron, J. L., Pergl, J., SchafFNeR, U., Sun, Y. \& PYŠEK, P. (2011): Ecological impacts of invasive alien plants: a meta-analysis of their effects on species, communities and ecosystems. - Ecology Letters 14: 702-708. https://doi.org/10.1111/j.1461-0248.2011.01628.x

Welter-Schultes, F. (2012): European non-marine molluscs, a guide for species identification. Planet Poster Editions, Göttingen, 674 pp.

Wiktor, A. (1987): Milacidae (Gastropoda: Pulmonata) - A systematic monograph. $-A n-$ nales Zoologici 41(3): 151-320.

WiктоR, A. (1996): The slugs of the former Yugoslavia (Gastropoda terrestria nuda - Arionidae, Milacidae, Limacidae, Agriolimacidae). - Annales Zoologici 46: 1-110.

Wiktor, A. (2000): Agriolimacidae (Gastropoda: Pulmonata) - A systematic monograph. Annales Zoologici 49(3): 347-590.

Zając, K. S., Gawee, M., Filipiak, A. \& Kramarz, P. (2017): Arion vulgaris Moquin-Tandon, 1855 - The aetiology of an invasive species. - Folia Malacologica 25(2): 81-93. https:// doi.org/10.12657/folmal.025.008

Zemanova, M. A., Knopf, E. \& Heckel, G. (2016): Phylogeographic past and invasive presence of Arion pest slugs in Europe. - Molecular Ecology 25: 5747-5764. https://doi. org/10.1111/mec.13860

Received March 26, 2020, accepted May 1, 2020, published August 14, 2020 